\title{
Building Bridges: A Practical Guide to Developing and Implementing a Subject-specific Peer-to-peer Academic Mentoring Program for First-year Higher Education Students
}

\author{
Ronika K. Power (Corresponding author) \\ Department of Ancient History, Macquarie University \\ New South Wales 2109, Australia \\ E-mail: ronika.power@students.mq.edu.au
}

Beverley B. Miles

Department of Ancient History, Macquarie University

New South Wales 2109, Australia

E-mail: beverley.miles@students.mq.edu.au

\author{
Alyce Peruzzi \\ Department of Ancient History, Macquarie University \\ New South Wales 2109, Australia \\ E-mail: alyce.peruzzi@students.mq.edu.au
}

Angela Voerman

Learning and Teaching Centre, Macquarie University

New South Wales 2109, Australia

Tel: 61-2-9850-7026_E-mail: angela.voerman@mq.edu.au

Received: September 8, 2011

doi:10.5539/ass.v7n11p75
Accepted: October 11, 2011

Published: November 1, 2011

URL: http://dx.doi.org/10.5539/ass.v7n11p75

\begin{abstract}
The Telemachus Ancient History Mentor Program (informally known as Tele's Angels) has been offering peer-led transition services to first-year students at Macquarie University since 2002. Tele's Angels volunteer Mentors create a 'learning community' by providing their first-year colleagues with transition assistance, academic support and resources, and networking for and amongst students and staff. Individual mentoring is offered, as well as free peer-support services which focus on developing academic skills and building social networks. The program also focuses on student leadership - a key objective is that Mentors themselves are beneficiaries of all activities, embodying the program motto: "to give is to receive". It is timely to report Tele's Angels' experiences to a wider audience and offer practical guidelines to those wishing to develop and implement subject-specific academic mentoring programs for first-year students in their own institutions.
\end{abstract}

Keywords: Peer-to-peer mentoring, First year in higher education, Academic skills, Transition support services, Learning resources, Student leadership, Widening participation, Student engagement

\section{Introduction}

The Telemachus Ancient History Mentor Program (informally known as 'Tele's Angels') was founded in 2002 by 9 second-year undergraduate students after observing a need for greater transition assistance, academic support, resources and networking during their own first-year (henceforth, FY) experience at Macquarie University. In agreement with Mann's (2001) five-fold approach to student engagement (offering solidarity, hospitality, safety, 
power-sharing and criticality), Tele's Angels aims to develop a 'learning community' by encouraging all involved in Ancient History teaching and learning - students and staff - to recognise our interdependence and responsibilities in assisting FY students through their academic and social transition into higher education (Gill et al. 2011: 63; Relf \& Sidoryn 2009; Dearn 1995). By offering free, peer-led academic skill-building activities, Tele's Angels creates spaces where students' confidence and abilities can grow in comfort and safety (Kift \& Nelson 2005: 228, 231).

The last 3 decades have witnessed a significant research increase in student engagement in general (Markwell 2007) and academic mentoring in particular (Eby et al. 2008; Eby et al. 2006; Roberts 2000: 160; McNamara \& Kelly 1995). This research indicates that mentors can facilitate immense positive change in individuals who have failed to respond to other forms of intervention, and confirms the many favourable benefits long-thought to be associated with mentorship, including positive effects on protégé behaviour, health, interpersonal relations, attitude and motivation. After guiding thousands of Ancient History students towards successful FY university experiences over the past 10 years, Tele's Angels can contribute substantial evidence to corroborate this research. Having successfully franchised the program across several diverse subject areas in recent years at Macquarie University, as well as receiving an ALTC AAUT for Programs that Enhance Learning in 2010, it is timely to report Tele's Angels' experiences to a wider audience. In alignment with the theme of this ASSJ special edition, this paper will introduce our program's aims and offer brief practical guidelines which outline the people, events, materials, resources and communications required to develop and implement a subject-specific academic mentoring program which 'closes the loop' for FY students by offering the skills they need to cross the bridge into higher education.

\section{Aims}

The Telemachus Ancient History Mentor Program's aims are mobilised in our Mission Statement, which reads as follows:

1. To build and maintain a caring and approachable academic and personal support network for FY students within the Macquarie University Ancient History community.

2. To provide FY Ancient History students with accurate information and advice regarding the University's facilities and procedures.

3. To foster and encourage self-initiated learning, self-confidence, self-esteem, communication and networking amongst FY Ancient History students.

4. To foster and encourage pride and passion for Ancient History education at Macquarie University amongst FY students, so that they may become actively involved within classes, the Department, and the greater university.

5. To build a legacy of care within the Telemachus Ancient History Mentor Program, so that FY students will recognise its worth and be proud to take over Mentor roles as second-year or more senior students.

6. In undertaking all of the above, we hope to learn and personally grow from this experience.

These aims materialise within an array of free, peer-led social and skill-building activities, including an annual Welcome Reception, Ancient History-specific Library Tours and workshops on Essay Writing, Ancient Language First Aid, Exam Advice, Degree Planning and Archaeological Fieldwork Application Advice, as well as seminars for the use of Digital Resources and Archaeological Fieldwork Pre-Departure Advice. In agreement with Durkin and Main (2002), the driving factor behind Tele's Angels' success is that its genesis and continuing evolution is governed by Ancient History undergraduate students for other Ancient History undergraduate students, resulting in seamless alignment between needs and service (cf. Gill et al. 2011: 66; Jenkins et al. 2009; O'Shea et al. 2009). The program also has a distinct focus on student leadership training and development - another of its key objectives is that Mentors themselves are also beneficiaries of all activities, embodying our motto: "to give is to receive" (Relf \& Sidoryn 2009; van der Meer \& Scott 2008: 75; Cox 2000: 207). Underpinning all activities is a commitment to our service priority: to never let a student enquiry go unanswered (Wilson 2009).

\section{People}

A Mentor program is only as strong as the Mentors themselves. Thus, we employ a proactive, invitational leadership model to ensure recruitment of quality Mentors who can deliver a consistent standard of care each year. Candidates are usually Ancient History students entering their second year of study or higher. New Mentors are identified by lecturers, tutors and team members as students of sound academic ability who also exhibit characteristics of leadership, charisma, compassion, creativity and community-mindedness, capped by an 
inexhaustible passion for Ancient History education (Terrion \& Leonard 2007: 152ff.). Once such individuals are identified, they are issued an invitation to join the team. Students are also welcome to self-nominate; many have contacted program coordinators directly to offer expressions of interest in becoming Mentors. Following an informal interview with one or more of the program coordinators, successful candidates enter an 'internship' period with the team. During this time, new recruits attend the following semesters' events as observers to gain exposure to program services and commitment requirements. Upon completion of this probationary period, recruits are free to decide whether or not they wish to continue as an inducted Mentor in the following academic year. Program participation is on a voluntary basis.

The induction of new Mentors is carried out by senior team members and takes place prior to the commencement of Semester 1 each year. Inductions provide opportunities for team bonding and establishing coherent frameworks; thereby ensuring familiarity with program objectives, operational structure, individual and group responsibilities and annual schedule. Defining Mentors' operational parameters is a key aspect of induction (Milne et al. 2007: 21; Nelson et al. 2006: 8). The role of a Tele's Angels Mentor is to provide academic support to FY Ancient History students. Mentors exclusively serve to provide accurate information and advice on the development of specific and generic skills required to succeed in the study of Ancient History at tertiary level (Kift \& Nelson 2005: 228). All student enquiries pertaining to the content or structure of individual units of study, or those of a more personal nature, are forwarded to the appropriate tutor, unit convenor, or campus welfare service (Colvin 2007: 166; Nelson et al. 2006: 8). The induction process is documented and updated annually following reflexive team debriefs which aim to improve the training experience for both senior and junior team members (Garvey \& Aldred 2000: 217). Inductions are substantiated through advice and informal supervision from the Head of Department, the Departmental Director of Learning and Teaching and a variety of other staff members (Milne et al. 2007: 21; Gravey \& Aldred 2000: 221). All training and service provision is further informed by recent pedagocial and First Year in Higher Education literature.

Orchestration of our annual events is the major vehicle by which Mentors obtain leadership and management training. Following a democratic process of discussion and negotiation, a Co-ordinator is appointed each year to plan and implement all events, along with four other Team Leaders who manage aspects of public relations and research facilitation, respectively. This approach promotes group solidarity and laterally distributes leadership experience over time. The leadership positions carry a great deal of responsibility and prove to be extremely rewarding for the appointees, who gain immeasurable skills via the management of service delivery and liaising with academic and administrative staff.

The program depends on staff sponsorship at all levels. Tele's Angels regularly liaises with the Head of the Department of Ancient History regarding all our activities and works closely with the Departmental Administrator to ensure logistical success. We keep our Faculty's Director and Associate Dean of Learning and Teaching abreast of developments in our portfolio and regularly communicate with the campus-based Transitions program and the Learning and Teaching Centre regarding pedagogical protocol. We are supported by the university executive and over the years have forged an open dialogue with our Faculty's Executive Dean as well as the DVC Social Inclusion, DVC Provost and Vice Chancellor.

\section{Events}

Events are placed strategically in Semester 1 to correspond with important dates in the university calendar. The first team meeting is held during Orientation Week to coincide with the Arts Faculty Academic Orientation, which we attend on an invitational basis to meet and greet the new FY cohort. Our official program launch, also known as the 'Welcome Reception' is held at the end of Week 3, giving FYs enough time to settle in to lectures and experience their first tutorial. Due to the challenges associated with student retention in language units, our Ancient Languages First Aid (ALFA) Seminar is held in Week 3, offering remedial skills and support before the Census Date (end of Week 4). Also offered in Week 4, our Library Tour adopts a processual approach to training students in Ancient History-specific research methods. Our Essay Writing Seminar is offered in Week 5 (well before first major essays are due), introducing the unique approaches required when dealing with ancient evidence and explicating Departmental marking and referencing criteria. The Archaeological Fieldwork Application Advice Seminar is held in Week 7, offering advice on building appropriate skills and experience and compiling competitive applications for participation in international archaeological excavations. The Degree Planning and Exam Advice Seminars are delivered during lectures in Week 12, so that students are well-prepared for exams in subsequent weeks; and well-informed for their subject selection over subsequent semesters. 
Considering that enrolment is open for students to commence studies in either semester at Macquarie University, Tele's Angels makes a specific effort to address the needs of mid-year-FY students by repeating our Semester 1 academic skills events in Semester 2. Further to this, we also offer Digital Resources and Archaeological Fieldwork Pre-departure Advice Seminars in Weeks 4 and 10 of Semester 2, respectively. Here, students wishing to excavate either antiquities or online resources (or both) are well-prepared and connected with Mentors who provide advice to first-time international- or cyber-travellers. The team de-briefs after each of our events to review and discuss how they may be improved for the following semester/year (Garvey \& Aldred 2000: 217).

\section{Communications}

Mentors are available for every field of undergraduate study offered by the Department of Ancient History, as well as general or administrative enquiries regarding the greater university. When in need of individual assistance, students contact us directly through our centralised email address (telesangels@gmail.com),website (telesangels.com.au), online learning channel (www.youtube.com/telesangels) or Facebook page. Our website is an interactive 'learning community' which facilitates broad dispersion of our services and resources while improving access for Macquarie's distance-education and online FY student communities. Our online learning channel, Tele-Vision, supports our mentoring activities by enabling distance-education students or those who are unable to attend our on-campus events to access our services and resources and engage with our Ancient History community (van der Meer \& Scott 2008: 70, 71). Our Facebook page enables Mentors and students to network and communicate regarding upcoming academic and social events in both virtual and corporeal facets of the Ancient History community.

Should Mentors encounter difficulty, they liaise with more senior team members for direction and support (we call this the 'Mentor Tree'; $c f$. Milne et al. 2007: 21; Nelson et al. 2006: 8). Google Group media is also employed as a repository where team members can access all program resources accumulated over the past decade of service. The Co-ordinator is the nexus for all team communications, as well as the liaison for all academic and professional staff.

\section{Materials and Resources}

Materials required for program activities are supplied by 4 internal sources. Our home Department provides the bulk of materials: ranging from overhead transparencies; white and coloured paper for photocopying; USB drives for the Co-ordinator and Team Leaders; a small food and drink budget for Welcome Reception refreshments; noticeboard space to display program information; computers/printers/photocopiers from allocated postgraduate student space; and a link to our program's website from the Departmental webpage. Campus $\mathrm{PR} /$ Marketing provide university t-shirts so the team can be identified during events; as well as university library bags which are filled with subject-specific resources and distributed as 'show-bags' at program events. The University Library produces subject-specific assignment guides which are included in the show-bags. Finally, the Faculty of Arts allows us to book Faculty-owned rooms for our on-campus events free-of-charge.

\section{Description of Impact}

Over the past 10 years 47 Tele's Angels Mentors have offered transition assistance, academic support and resources to over 10000 enrolments across 11 FY Ancient History and Ancient Language units. We have positively influenced student retention: the mean loss rate for FY Ancient History subjects at Macquarie University from 2006-2010 is notably less than mean-loss rates for the University, sector and nation. Students consistently indicate their satisfaction with our services and resources through our formal feedback mechanism, the Tele's Angels Student Experience Survey, and also provide impromptu testimonials via email or in person at our service events (Milne et al. 2007: 21). Students further endorse the program by subscribing to its 'legacy of care' and becoming Mentors themselves in their second or senior years of study (Relf \& Sidoryn 2009; Cox 2000: 207; Roberts 2000: 160). One of the major program benefits is that it serves as a bridge to facilitate and strengthen interactions between FY students and staff, consolidating the sense of an Ancient History 'community' as opposed to 'department' (Gill et al. 2011: 63; Relf \& Sidoryn 2009; Dearn 1995). Considering the nature of our discipline, it is particularly appropriate for dialogues between and amongst pedagogical generations to perpetuate and reshape the study of history, both in terms of content and approach. The program also builds and fosters learning relationships of varying configurations: amongst FY students themselves; between junior and senior students; and amongst the Mentor team (Wilson 2009; van der Meer \& Scott 2008: 74, 75). As key beneficiaries of the program, Mentors develop strong leadership, communication, organisation and management skills and extend their knowledge of Ancient History subject matter. Of particular benefit is Mentors' exposure to the entire spectrum of the student body, working with individuals from diverse equity backgrounds with a range of access needs (Wilson 2009). In this way, as students move through the program and 
transition into higher degree research, their experience as Mentors readily prepares them to become tutors in undergraduate subjects. The program also benefits the greater university via wider participation across campus (Relf \& Sidoryn 2009), with Mentors serving as student representatives on a raft of institutional learning and teaching committees, panels and initiatives.

\section{Conclusion}

After 10 years of service at Macquarie University, the Telemachus Ancient History Mentor Program seeks to extend its 'legacy of care' across the tertiary education sector. Having successfully franchised the program across several diverse subject areas in recent years at Macquarie University, the program has developed steadfast expansion guidelines for its duplication elsewhere. With a view to achieving this aim, this paper has provided an introduction to the program's aims and offered brief practical guidelines which outline the people, events, materials, resources and communications required to develop and implement a subject-specific academic mentoring program for FY students as they transition into higher education. For further information, materials or collaboration, readers are encouraged to contact the corresponding author.

\section{References}

Colvin, J. W. (2007). Peer tutoring and social dynamics in higher education. Mentoring and Tutoring: Partnership in Learning, 15(2), 165-181. http://dx.doi.org/10.1080/13611260601086345

Cox, E. R. J. (2000). The call to mentor. Career Development International, 5(4), $202-210$. http://dx.doi.org/10.1108/EUM0000000005357

Dearn, J. (1995). Creating a More Supportive Culture for First Year University Science. In First Year Experience 1995 Conference, 'Travelling Through Transition', QUT Brisbane, 11-14 July. [Online] Available: http://www.fyhe.com.au/past_papers/papers95.htm (August 28, 2011).

Durkin, K., \& Main, A. (2002). Discipline-based study skills support for first-year undergraduate students. Active Learning in Higher Education, 3 (1), 24-39. http://dx.doi.org/10.1177/1469787402003001003

Eby, L. T., Allen, T. D., Evans, S. C., Ng, T., \& DuBois, D. L. (2008). Does mentoring matter? A multidisciplinary meta-analysis comparing mentored and non-mentored individuals. Journal of Vocational Behaviour, 72, 254-267. http://dx.doi.org/10.1016/j.jvb.2007.04.005

Eby, L. T., Durley, J. R., Evans, S. C., \& Ragins, B. R. (2006). The relationship between short-term mentoring benefits and long-term mentor outcomes. Journal of Vocational Behaviour, 69, 424-444. http://dx.doi.org/10.1016/j.jvb.2006.05.003

Garvey, B. \& Aldred, G. (2000). Developing mentors. Career Development International, 5(4), $216-222$. http://dx.doi.org/10.1108/EUM0000000005359

Gill, B., Ramjan, L., Koch, J., Dlugon, E., Andrew, S., \& Salamonson, Y. (2011). A standardized orientation program for first year undergraduate students in the College of Health and Science at UWS. A Practice Report. The International Journal of the First Year in Higher Education, 2(1), 63-69. http://dx.doi.org/10.5204/intjfyhe.v2i1.48

Jenkins, A. L., \& Miyazaki, Y. Janosik. (2009). Predictors that Distinguish First-Generation College Students from Non-First Generation College Students. Journal of Multicultural, Gender and Minority Studies, 3(1). [Online] Available: http://www.scientificjournals.org/journals2009/articles/1429.pdf (August 28, 2009).

Mann, S. J. (2001). Alternative Perspectives on the Student Experience: alienation and engagement. Studies in Higher Education, 26(1), 7-19. http://dx.doi.org/10.1080/03075070020030689

Markwell, D. (2007). The Challenge of Student Engagement, Key-note address - Teaching and Learning Forum 2007. University of Western Australia, 30-31 January 2007. [Online] Available: http://www.catl.uwa.edu.au/_data/page/95565/Student_engagement___Don_Markwell___30_Jan_2007.pdf (August 21, 2011).

McNamara, E. A., \& Kelly, B. (1995). Where does peer assisted learning belong? A comparative analysis of schemes for first year students offered by academic departments and student services. The Inaugural Pacific Rim First Year Experience Conference: Travelling Through Transition. Brisbane 11-14 July 1995. [Online] Available: http://www.fyhe.com.au/past_papers/papers95.htm (August 21, 2011).

Meer, J. van der, \& Scott, C. (2008). Shifting the Balance in First-Year Learning Support: from Staff Instruction to Peer-Learning Primacy. Australasian Journal of Peer Learning, 1, 70-79. 
Milne, L., Keating, S., \& Gabb, R. (2007). Student Peer Mentoring at Victoria University. Postcompulsory Education Centre, Victoria University. [Online] Available: http://tls.vu.edu.au/portal/site/research/resources/student_peer_mentoring_at_VU_final_report.pdf (August 28, 2001).

Nelson, K. J., \& Kift, S. M. (2005). Beyond curriculum reform: embedding the transition experience. In Brew, A. \& Asmar, C. (Eds.) Proceedings HERDSA 2005 28, pp. 225-235. The University of Sydney, Sydney, Australia. [Online] Available: http://eprints.qut.edu.au/3944/1/3944.pdf (August 21, 2001).

Nelson, K. J., Kift, S. M., Humphreys, J. K., \& Harper, W. E. (2006). A blueprint for enhanced transition: taking an holistic approach to managing student transition into a large university. First Year Higher Education Conference, 12-14 July 2006, Gold Coast, Australia. [Online] Available: http://eprints.qut.edu.au/4557/1/4557_1.pdf (August 28, 2011).

O'Shea, S., Vincent, M., Calder, A, \& Handley, P. (2009). Peer transition programs: Run by students for students. In First Year in Higher Education Conference 2009, Townsville, 29 June-1 July. [Online] Available: http://www.fyhe.com.au/past_papers/papers09/content/pdf/1 A.pdf (August 28, 2011).

Relf, S., \& Sidoryn, T. (2009). Stars on campus: Designing student mentoring programs to build mentors' sense of community, connections and engagement with other students and the university. In First Year in Higher Education Conference 2009, Townsville, 29 June-1 July. [Online] Available: http://www.fyhe.com.au/past_papers/papers09/content/pdf/3D.pdf (August 28, 2011).

Roberts, A. (2000). Mentoring Revisited: a phenomenological reading of the literature. Mentoring and Tutoring, 8(2), 145-170. http://dx.doi.org/10.1080/713685524

Terrion, J. L., \& Leonard, D. (2007). A Taxonomy of the Characteristics of Student Peer Mentors in higher Education: Findings from a Literature Review. Mentoring \& Tutoring: Partnership in Learning, 15(2), 149-164. http://dx.doi.org/10.1080/13611260601086311

Wilson, K. (2009). The impact of institutional, programmatic and personal interventions on an effective and sustainable first-year student experience. In First Year in Higher Education Conference 2009, Townsville, 29 June-1 July. [Online] Available: http://www.fyhe.com.au/past_papers/papers09/ppts/Keithia_Wilson_paper.pdf (August 28, 2011). 